\title{
Higher education and sustainable development goal 16 in fragile and conflict-affected contexts
}

\author{
Sansom Milton ${ }^{1}$ (D) \\ Published online: 28 September 2020 \\ (c) The Author(s) 2020
}

\begin{abstract}
Sustainable Development Goal 16 commits to 'promote peaceful and inclusive societies for sustainable development, provide access to justice for all and build effective, accountable and inclusive institutions at all levels'. While the concerns of SDG16 with violence reduction, rule of law, and governance are relevant to all societies, this paper focuses on fragile and conflict-affected countries, many of which have the hardest task in achieving SDG16. It analyses how higher education can contribute towards—or detract from-SDG16 through teaching, research, governance, and external leadership. It then analyses four dynamics influencing the agency of universities in fragile and conflict-affected contexts in engaging with SDG16: resource mobilisation and the public good; securitisation; academic freedom, insecurity, and politicisation; and tensions between demands for localisation and the universalising logics of liberal peacebuilding models and the SDGs.
\end{abstract}

Keywords Higher education · Sustainable development goals · SDG16 · Peace · Governance $\cdot$ Fragile states

\section{Introduction}

The Sustainable Development Goals, launched in 2015, are notable for the inclusion of under-analysed issues in global development norms including the environment and quality education. In particular, SDG16 on peace, justice, and inclusion is a bold advancement in a field accustomed to viewing these issues as 'political' and outside the remit of development policy. Whilst the post-2015 agenda provides an improved framework for addressing inter-connected issues of conflict and development, the post-2015 world has become less peaceful for the first time in a generation. In 2014, the number of battlefield deaths increased, reversing a long decline to reach the highest level since the end of the Cold War (Dupuy et al 2016). Whilst this alarming statistic has fallen by $49 \%$ between 2014 and 2018 , in 2018, the number of state-based armed conflicts was much higher than a decade ago (Strand et al 2019).

Sansom Milton

Sansom.milton@gmail.com

1 Researcher, Center for Conflict and Humanitarian Studies, Arab Center for Research and Policy Studies, Doha, Qatar 
Post-2015 achievement has been mixed. Over the initial 4 years, 'available data indicates that progress towards SDG16 so far is 'uneven' at best' (Bhargava et al 2019, p.vi). Whilst a key SDG message is to leave no one behind, fragile states-those with 'a fundamental failure of the state to perform functions necessary to meet citizens' basic needs and expectations' (Mcloughlin 2012, p.9) —are at particular risk, with only 18\% 'on track' to meet selected SDG targets related to meeting basic needs compared to 35\% of low- and middle-income countries (Samman et al. 2018). Given the scale of SDG-related challenges facing fragile and conflict-affected states, there is need for research on how to harness existing resources towards sustainable development and challenges of conflict, injustice, and exclusion that threaten development progress. Many studies on higher education and SDGs have been published over the past 5 years. Whilst studies explore how universities can contribute towards all SDGs (SDSN 2017; McCowan 2019), there is little comparative analysis of higher education and SDG16 in fragile and conflict-affected contexts.

This paper provides such an analysis of major trends and emerging evidence on how higher education in fragile and conflict-affected states can contribute towards building peaceful, just, and inclusive societies. Examples are offered from various fragile states, with focus on the most fragile ${ }^{1}$ and conflict-affected contexts including Afghanistan, Syria, Yemen, South Sudan, Somalia, and the Gaza Strip — those most at risk of being left behind in realising the post-2015 development agenda. Whilst there is variation between conflictaffected countries including in university-state relations, regime type, conflict context, or enrolment level, common challenges including insecurity, instability, and displacement afflict these countries to varying degrees of intensity. The paper begins with a brief note on methodology followed by an overview of the SDG16 and the position of higher education in the SDG agenda. It then analyses the role of higher education in contributing towards SDG16 in education, research, external leadership, and governance and operations. Following this, four cross-cutting challenges facing higher education and SDG16 are examined.

\section{Methodology}

The article is based on a combination of field-based and desk-based research on higher education in fragile and conflict-affected contexts. Desk-based research involved review of both academic and policy literature in English relating to SDG16 and broader debates in related areas of development policy in fragile states, conflict, and peacebuilding. This involved comprehensive literature searches to identify sources that can inform original analysis of this unexplored topic. Primary data was collected from multiple sources including interviews and focus groups. Most data was collected for the purposes of the paper during 2019 and 2020, with additional observations and re-interpretation of interview data from years of research on higher education in fragile and conflict affected contexts also utilised.

Interviews were conducted across various country contexts, both face-to-face and online. Some interviews were undertaken by the authors in English as the primary working language whilst others - in particular interviews carried out in 2019 and 2020 in fragile and conflict-affected contexts-were conducted in local languages by trained research assistants who translated and transcribed interview data. Initial interviews enabled analytical

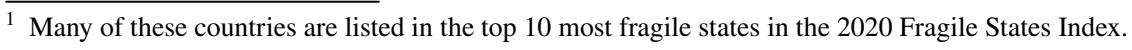


refinement of questioning strategies and exploration of gaps in data in later interviews, which was followed by qualitative thematic analysis. Interviews enabled the exploration of worldviews and beliefs of higher education communities in terms of how they conceptualise the potentialities and limits of the agential role of the university in contributing towards peace, governance, and justice.

In the first instance, purposive sampling was employed to identify individuals for key informant interviews with academics, students, and experts with specialised knowledge on the issues involved. Snowball sampling was then utilised to arrange for additional interviews in several country contexts, in particular Syria, Gaza, and Afghanistan. Interviewees are diverse in terms of career stages and job positions, with over-representation of social sciences and law academics/students. Whilst all countries in which research was conducted possess at least some technical and vocational tertiary institutions, analysis focuses largely on the university level. Due to ethical considerations and the sensitivity of the subject matter, and the risk of attacks on higher education which are particularly high in fragile and conflict-affected conflicts, all names have been anonymised with brief biographical details including names of universities and in some cases faculty or rank disclosed.

\section{Sustainable Development Goal 16}

The Sustainable Development Goals are the successor to the Millennium Development Goals, the first global development framework during 2000-2015. The SDGs have a number of defining characteristics. Firstly, there are many synergies-interactions with positive effects-across and between the 17 SDGs and 169 targets, but also trade-offs (Donoghue and Khan 2019). Secondly, whilst MDGs were a binding global agreement, SDGs represent universally applicable, non-binding, aspirational global norms. Governments and stakeholders have greater freedom to focus on priority SDGs and tailor means of implementation to particular contexts (Janoušková et al 2018). Thirdly, SDGs represent an ambitious, holistic agenda incorporating environmental issues, inequalities, and peace into global development norms.

SDG16 reflects these characteristics, committing to 'promote peaceful and inclusive societies for sustainable development, provide access to justice for all and build effective, accountable and inclusive institutions at all levels'. Firstly, there is much synergy between SDG16 and other goals, reflecting increased acknowledgement that peace is necessary for development (Collier et al. 2003) and the need for legitimate institutions and security for breaking out of cycles of conflict (World Bank 2011). Interdependence between progress on SDG16 and other goals is evidenced for SDG1 on No Poverty given that on current trends by 2030 fragile and conflict-affected states could account for $60 \%$ of the extreme poor globally (World Bank 2018).

Secondly, SDG16 is amongst the most aspirational SDGs. This largely results from compromise necessary for a governance-centric SDG. Russia and China saw rule of law monitoring as sovereign interference, and the finalised SDG16 was only accepted once Rule of Law was dropped from the title (Kamua et al 2018, p.270). Additionally, Brazil, India, and others argued that SDG16 risked securitising development. Crucially, the g7+ grouping of fragile states championed SDG16, avoiding its framing as a Northern imposition on the global South. Thirdly, SDG16 itself is a holistic goal. In SDG negotiations, many states advocated splitting SDG16 into two goals-on peace and governance, reflecting its wide 
scope addressing issues including citizen security, human trafficking, public participation, child abuse, and unsentenced prisoners (Kamua et al 2018, p.269).

\section{Higher education and the SDGs}

Whilst higher education is not a major SDG pillar, the SDGs do place greater emphasis on higher education than the MDGs where the sector was peripheral. Social returns of tertiary education have long been under-estimated in development theory, including in "strengthening of both formal institutions and social norms, in areas such as governance, public services and the environment' relevant to SDG16 (Oketch et al. 2014, p.52). The notion that higher education has low social returns informed the MDGs, in particular on basic education, which whilst the most successful goal, brought about unintended consequences in fragile and conflict-affected contexts. Lockhart and Vincent (2013, p.35) write that:

MDG teams used the primary education goal as a planning tool, insisting that resources be concentrated on primary education at the expense of secondary and tertiary education as well as vocational training. As a consequence a critical skills gap looms, further complicating the task of creating capable national institutions.

Higher education figures in SDGs in three ways: standalone targets under SDG4, SDG4 targets applicable to all educational levels, and an instrumental role in SDG achievement (McCowan 2019). Firstly, Target 4.3. Commits to 'by 2030, ensure equal access for all women and men to affordable and quality technical, vocational and tertiary education, including university'. Additionally, Target 4.b. commits to 'substantially expand globally the number of scholarships available to developing countries'. Whilst it is beyond the scope of this paper to analyse SDG4, it is an insufficient guide for harnessing higher education towards any SDGs. In particular, scholarships are a regressive form of development assistance that often benefit donor country universities and in fragile contexts are even more likely to perpetuate brain drain than in stable contexts whilst also representing an opportunity cost against domestic system-wide transformation (Milton 2018).

SDSN (2017) proposes a framework identifying four main functions through which higher education can contribute towards the SDGs - teaching and learning; research and development; operations and governance; and external leadership (see Table 1). This framework-which can be applied to any society globally-focuses largely on the agency of universities and practical and policy implications of contributing directly towards SDGs. As such, it is not an analytical framework that can identify all direct and indirect pathways by which higher education can contribute towards core SDG16 terms of peace, justice, and institutions. Such comparative analysis of causal mechanisms underlying the higher education-fragility relationship is beyond the scope of the paper. Rather, the focus is on the scope of university agency in engaging SDG16 and challenges and opportunities faced in fragile and conflict-affected contexts. The paper contributes towards a growing literature on university agency on issues including peacebuilding and resistance (Millican 2018), post-conflict recovery (Milton 2018), and conflict transformation (Brewer 2018). The following section utilises the SDSN framework as a useful heuristic device for classifying university agency in engaging with SDG16-related areas in fragile and conflict-affected contexts. The paper then moves on to consider some cross-cutting issues facing university agency in engaging SDG16. 


\section{Education}

The education mission of universities can contribute towards SDGs including through curricula, extra-curricular activities, or mobilising youth for sustainable development (SDSN 2017). University education during conflict often faces challenges including worsening access, quality and equity and disruption to learning processes. Yet, despite challenges, even in the most fragile situations — such as Yemen, Syria, and South Sudan-higher education of some form nearly always continues. Furthermore, the educative function is disproportionately significant in fragile and conflict-affected contexts-relative to research, external engagement, and governance — as most universities are primarily teaching institutions (Milton 2018).

Teaching SDG16-related issues is the most direct way to contribute towards SDG16. In terms of curricula, amongst the most-analysed contributions is peace and conflict studies, which is a common intervention in conflict-affected contexts. Centres for peace related education and training are present in many fragile contexts including Afghanistan, Somalia, the Central African Republic, and Sudan/South Sudan where there are at least nine centres for peace and conflict/development studies resulting from the Comprehensive Peace Agreement. Whilst new degrees on peace and governance can foster expertise, locating these subjects within a single discipline lessens the potential to educate a critical mass of students and faces obstacles to establishing new disciplines. For instance, in Syria, academic culture inhibits such new teaching programmes, with a general 'impression that ridicules all issues related to social sciences, let alone peace, government and the rule of law'. ${ }^{2}$

Rather than compartmentalise peace impact in a single programme, issues related to conflict and governance can be integrated throughout curricula. A comparative study of higher education in post-conflict contexts finds that university curriculum is limited in contributing towards peace because 'the thematic content of students' learning is often tailored to specific subjects (i.e. specific faculties, departments, and schools of thought) that do not lend themselves to peace-building' (Feuer et al. 2013, p.10). Similarly, disciplinary boundaries vary in the extent that they map onto SDG16. Law and political science departments are of direct relevance to justice and governance. For instance, in Syria virtually no teaching related to governance or rule of law occurs outside of these disciplines. ${ }^{3}$ Yet, various SDG16 targets have no clear disciplinary home. The United Nations Office for Drugs and Crime in 2015 resolved that 'higher education is a key catalyst for crime and the rule of law' and developed many free, online thematic modules on issues related to SDG16 including anti-corruption, crime, and counter-extremism that 'tend to get overlooked' in comparison to other SDGs. ${ }^{4}$ The project 'generated a lot of traction in fragile states' beyond initial expectations and involves capacity building on utilising modules, across various disciplines outside of conventional focus on law schools, including in Afghanistan, Somalia, and Zimbabwe. The SDGs represent a holistic framework, and higher education can foster critical thinking to work across disciplinary and sectoral boundaries.

Universities are also valued for their mobilisational role in coalescing student collective action on the SDGs. On the one hand, mobilisation towards SDG16 related issues takes place in formal, institutional contexts. UN agencies and NGOs have, for instance,

\footnotetext{
2 Interview. Syrian researcher. Arab Center for Research and Policy Studies. Doha, Qatar. June 2020.

3 Online interview. Former Deputy Minister of Higher Education, Syrian Interim Government.

${ }^{4}$ Interview. Two senior officials. United Nations Office for Drugs and Crime. April 2020.
} 
Table 1 Overview of university contributions to the SDGs

\begin{tabular}{ll}
\hline Function of higher education & University contributions to the SDGs \\
\hline Education & $\bullet$ Education for sustainable development \\
& $\bullet$ Jobs for implementing the SDGs \\
& $\bullet$ Capacity Building \\
& $\bullet$ Mobilising young people \\
& $\bullet$ Research on the SDGs \\
Research & $\bullet$ Interdisciplinary and transdisciplinary research \\
& $\bullet$ Innovations and solutions \\
& $\bullet$ National and local implementation \\
& $\bullet$ Capacity building for research \\
& $\bullet$ Public engagement \\
& $\bullet$ Cross-sectoral dialogue and action \\
External leadership & $\bullet$ Policy development and advocacy \\
& $\bullet$ Advocacy for sector role \\
& $\bullet$ Demonstrate sector commitment \\
& $\bullet$ Governance and operations aligned with SDGs \\
& $\bullet$ Incorporate into university reporting \\
\hline
\end{tabular}

Source: SDSN (2017)

implemented projects defining university students as 'agents of change' for SDGs, supporting awareness raising, community engagement, volunteering, and devising innovative solutions to developmental challenges. Such mobilisation towards SDG16-related issues in fragile and conflict affected contexts includes, for instance, Iraqi and Afghan universities, in collaboration with UN missions, holding anti-corruption trainings in support of legal reform. On the other hand, in many fragile and conflict-affected contexts, the more significant role of student mobilisation on issues related to governance, peace, and justice is not through formal channels but rather in student activism and protest. For instance, in 2019 , tens of thousands of Iraqi university students mobilised in protests against incompetent governance and rampant corruption, constituting an important social force in southern governorates where they represented approximately $40 \%$ of protestors and were viewed as security threats. ${ }^{5}$ Similarly, popular mobilisation by Sudanese universities has long been significant in toppling regimes and played a large role in the April 2019 revolution. Such mobilisation of students protesting corruption, exclusion and marginalisation, or even state-sanctioned violence can drive social change yet also entails particular risks of securitisation and violence that are further explored later in this paper.

5 Online interview. Student, Qadisiyah University. June 2020. 


\section{Research}

Higher education can also contribute as a primary actor in SDG-related research production. Research environments in fragile and conflict-affected settings are typically characterised by various features, including predominance of teaching institutions, reduced funding, isolation from global academia, and erosion of research capacities, in particular brain drain (Milton 2018). University research capacities are frequently low and clustered in a few elite, national institutions. Yet, despite challenging circumstances, individual researchers and universities caught in conflict are able to produce research on developmental challenges.

For various reasons, SDG16-related research in the most fragile contexts can be characterised as donor-driven. Firstly, donors and external funders often drive demand for such specialised research as peace and governance are increasingly prominent on development research agendas. For instance, a study of Somalia's research system finds low local demand for statebuilding- and peacebuilding-related research with research agendas shaped by donors and consequently weak Somali knowledge ownership (INASP 2018). Secondly, SDG16-relevant research capacity in fragile contexts may also be weak in societies with little recent conflict exposure, with greater specialised capacities developed in protracted conflict contexts.

Whilst SDG16-related research is produced in fragile and conflict-affected contexts, it is primarily done so outside of higher education. Donors are often cautious in engaging publicly funded universities perceived to lack sufficient autonomy to produce independent research, and hence much donor-funded research is conducted by private research institutes or consultants. For instance, a DFID report on Afghanistan recommends that:

Especially for sensitive or controversial topics and issues, it is not realistic to expect objective and disinterested research from public sector institutions, so investment in and encouragement of non-governmental producers of research should continue (Fishstein et al. 2012, p.59).

These issues connect to broader challenges facing research partnerships as a modality for SDG16-relevant research. Demand from Northern knowledge funders and producers conducting political research for local researchers in conflict zones has increased in the twenty-first century as increasingly violent conflicts, more frequent attacks on aid workers and journalists, and more stringent university risk assessment and insurance policies create access obstacles for researchers (Malejacq and Mukhopadhyay 2016). A key challenge facing universities in fragile and conflict-affected contexts-amongst the most peripheral actors in global academia - is navigating SDG16-related research opportunities as genuine partners rather than sub-contracted research assistance.

Partnerships can be of mutual benefit with Northern universities offering specialist expertise and greater resources whilst Southern universities provide deep contextual knowledge and fieldwork access (Pherali and Lewis 2019). However, many research partnerships do not live up to ideals of mutually beneficial, collaborative engagement. Frequently, there are shortcomings including insufficient recognition of local researcher contributions, shortterm partnerships, inadequate capacity building, and pre-determined research agendas (Fast 2019; Pherali and Abu Moghli 2019). For instance, in South Sudan, whilst donors fund international research partnerships, 'most national researchers are largely employed as data collectors or research catalysts; they are not genuine partners' (Kuol 2019). 
Several Afghan academics critiqued this dynamic in donor-driven research for side-lining universities, calling to involve institutions rather than individuals which would more effectively develop Afghan capacities. ${ }^{6}$ Furthermore, the project-driven research culture is viewed as limiting the scope of social inquiry into peace- and governance-related issues as 'private consultancies conduct the research only for the purpose of a project, not as an effective research method to help to resolve the problem(s) ${ }^{7}$ In short, universities, despite the challenges, offer a more sustainable, long-term platform through which to genuinely build capacity, benefit the public good, and promote critical research rather than the aboveanalysed donor-driven subcontracting of private research consultancies.

\section{External leadership}

Globally, universities can act as a partner for SDG implementation, research, and policy engagement. Universities are a natural lead partner in 'cross-sectoral implementation of the SDGs, providing an invaluable source of expertise in research and education on all sectors of the SDGs, in addition to being widely considered as neutral and influential players' (El-Jardali et al. 2018). SDG16 in particular provides an opportunity for Northern universities in the core of global academia to mobilise resources and demonstrate external impact in addressing grand challenges including peace, governance, and global injustice. This section will analyse whether universities in fragile and conflict-affected contexts can and should make SDG16 a central part of their service mission through external impact, public engagement, and advocacy.

Firstly, whilst some universities in fragile and conflict-affected contexts are actively engaging with SDG16, overall awareness is low. There are examples of direct SDG16 engagement in the most fragile contexts. For instance, in its 2018 Voluntary National Review, Sudan highlights Afhad University for Women Trauma Center treating female war victims and Khartoum University's Peace Research Institute (GoS 2018). However, Voluntary National Reviews for 2019 submitted by fragile and conflict-affected states including Iraq and Timor-Leste exhibit minimal reporting on SDG-relevant university activities. Kateb University in Afghanistan held a conference with high-level political involvement on SDGs and universities, including specifically on SDG16 in relation to combatting crime. Yet, such an engagement occurred in a context where only $2 \%$ of universities are aware of SDGs (Shefaie 2019).

External leadership for SDG16 can take many forms. Universities are valued for their convening power-often based on perceived neutrality and objectivity-in bringing together various stakeholders to deliberate over public issues. Whilst neutrality is difficult for any social institution to maintain in conflict-affected societies, there are positive examples of such a role in fragile contexts. For instance, the Solomon Islands National University offered a truly national university providing neutral policy space to discuss vital postconflict issues that was unavailable in private institutes, although donors over-looked this role (Barbara and Walsh 2018). Other universities in fragile contexts have engaged political processes at high levels. For instance, the University of Khartoum Initiative was an important initiative during Sudan's political transition in April 2019.

\footnotetext{
${ }^{6}$ Online interviews. Four Afghan academics. Universities of Kandahar, Marib, and al-Kateb. May 2020.

7 Online interview. Faculty member. Kandahar University. May 2020.
} 
In terms of external engagement in influencing SDG-16 related policy through research, there are various barriers to research uptake and use by policy-makers. In many fragile states-which by definition suffer from institutional weakness-bureaucratic capacity to utilise research in evidence-based sustainable development policy is often weak. For example, in South Sudan after years of conflict and ineffective statebuilding efforts 'government officials are often not capable of interpreting, analysing and using research evidence in policy' (Jok 2016). There are, however, positive cases of research use. For instance, in postconflict Sierra Leone, local researchers increasingly influenced British-led justice reform policy as the country stabilised, research-policy networks formed, and research utilisation became institutionalised (Varisco 2018).

Yet, in some fragile states, under-development of higher education itself somewhat paradoxically affords greater social capital and access to policy-makers. In the Lake Chad Basin, whilst Chad has much lower enrolment than neighbouring Cameroon or Nigeria, 'those who do attend university form an elite cadre of individuals with greater opportunity and access to positions in policy creation and governance' (Hoinathy and Eizenger 2019, p.2). In the Central African Republic, with similar enrolment levels, the President is also the former Rector of the University Bangui, fostering university-state relations. In Afghanistan, many professors have served as ministers or other senior roles, creating individual opportunities to influence policy based on elite networks-whilst the current President Ashraf Ghani is credited with the delivering the most productive period at Kabul University in the post-2001 period under his leadership. ${ }^{8}$

\section{Operations and governance}

Universities can contribute towards building peaceful, just, and inclusive societies by incorporating these values in their operations and governance. In conflict-affected contexts, some aspects of university operations take on greater significance than in more stable contexts. SDSN (2017) recommends that universities should take a stand against corruption, terrorism, and violence whilst policies, including for investment and procurement, should not support individuals or institutions threatening to SDG16 involved in human trafficking, crime, or arms dealing. Living up to this ideal is a particular dilemma in fragile states where lines between crime, corruption, and conflict often blur and where universities faced with major financial, security, and logistical challenges may be left with little choice but to accept funding or protection from any source available. For instance, after the defeat of the Islamic State, Mosul University faced the dilemma of accepting security from Popular Mobilization Units - which stood accused of abuses — spreading fear and provoking sectarian tensions. ${ }^{9}$ Similarly, universities in besieged Gaza have little choice but to cooperate with Hamas-a proscribed terrorist organisation. ${ }^{10}$

Higher education can also support SDG16 governance dimensions by modelling participation and strong institutions. This can be achieved through open and transparent university governance, for instance, by student or community representation on university governing boards, meritocratic appointments, or offering space for students to practice

\footnotetext{
${ }^{8}$ Interview. Former Kabul University student. Doha, Qatar. May 2020.

9 Interview. Lecturer in Comparative Literature, Mosul University. February 2018.

${ }^{10}$ Interviews. Gazan academics. Gaza. 2018-2019.
} 
democratic organising. A comparison between responses to student disorder at two universities in Côte D'Ivoire finds permitting student unionism, participatory university governance, and respecting free expression enabled an open environment whilst repressive responses inflamed campus-based conflict and limited university contributions to peacebuilding (Babo 2019). However, bad university governance can have an inverse effect. For instance, private universities run by Afghan power-holders are frequently subject to nonmeritocratic practices, propagation of narrow ideological agendas, and aggressive campusbased student recruitment, thus powerfully shaping political socialisation of students in ways that model particularistic and patronage-based politics (Ibrahimi 2014).

Addressing exclusion and marginalisation is a key mechanism through which universities can support SDG16 and the overall SDG message to leave no one behind. In divided, conflict-affected societies university campuses are often home to students from a much more diverse background than in schools in their home cities. University governance can mediate whether this heterogeneity serves as a force for peacebuilding or a flashpoint for conflict. For instance, Queen's University Belfast's 'own structures and policies began to model the new inclusive society people aspired to in Northern Ireland, through a vigorous and encompassing equality agenda that promoted fair employment, gender equality and abolished discrimination against Catholics' (Brewer 2018, p.72). However, when poorly managed, inter-communal conflict can occur on campus. For instance, university handling of religious observances sparked sectarian tension on campuses in post-2003 Iraq, where an Iraqi professor reported 'you don't feel like you are in an academic institution; you feel like you are in a mosque and don't have the right to criticise'. ${ }^{11}$

\section{Cross-cutting dynamics for higher education and SDG 16}

Central to all the forms of engagement with SDG16-whether education, research, external leadership, or governance-is whether universities in conflict can become agents for peace, justice, and strong institutions. The potential of universities in fragile and conflictaffected contexts becoming champions for sustainable development brings about a number of opportunities but also trade-offs. This section presents four cross-cutting dynamics facing higher education in contributing towards SDG 16 in fragile and conflict-affected contexts.

\section{Resource mobilisation, developmentalism, and stateness}

One major cross-cutting challenge is resource mobilisation. This is not surprising as many of the most fragile contexts are low-resource environments (see Table 2). In countries with very low access to higher education, such as Chad and Central African Republic each with $3 \%$ gross tertiary enrolment, mobilising resources to engage SDGs will be even more challenging. Yet, even in fragile contexts with greater resource availability, funding is still a major obstacle. For instance, Iraqi universities' role in monitoring SDG16 targets and indicators is limited by low funding streams for surveys. ${ }^{12}$ SDG16 is itself, however, an

\footnotetext{
11 Interview. Professor, Al-Mustansiriya University. Amman, Jordan. February 2011.

12 Online interview. Senior Project Manager, UNDP Iraq. May 2020.
} 
opportunity for universities in fragile and conflict-affected contexts to mobilise resources by framing their engagement with peace- and governance-related issues as aligning with SDG16. Many UN agencies are making funding dependent on engaging the SDGs and SDG16 is naturally of relevance in fragile contexts. ${ }^{13}$ Yet, in interviews, resource constraints were rarely cited, with major obstacles of SDG16 engagement being political.

Beyond resource availability, the notion that universities in conflict zones should engage SDG16 may be met with scepticism. A major critique of the 'developmental university'in which commitment to development is a central purpose of higher education-is that it overburdens developing world university systems already struggling with austerity, poor material conditions, and brain drain and thereby detracts from providing 'good normal education' (Court 1980). More recently, in many low- and middle-income countries, core academic demands of expanding access and improving quality compete with service missions of policy relevance and nurturing partnerships (El-Jardali et al. 2018). It may be reasoned that under conflict and fragility, additional stresses of violent attacks on universities, reduced funding, or isolation of from global academia amplify this dilemma. In considering the importance of national context for the applicability of the New Flagship University model-a leading national university characterised by a commitment to public service, regional economic development, and technology transfer-Douglass (2016, p.106) writes that 'failed states or highly centralised and controlling oligarchies create significant limits on the ability of universities to be fully engaged in the Flagship ideal'.

Another consideration in gearing higher education towards SDG16 is the nature of the state in contexts of fragility which problematises state-university relations. The SDG framework is universal in scope yet organised around a state-centric framework of targets and indicators, including national human rights institutions, public participation, and access to justice. Yet in focusing on the most fragile states, the issue of how universities can contribute towards state-level targets faces the fundamental challenge that these attributes are by definition weak and contested. Whilst territorial fragmentation is not a new conflict trend, several notable post-2015 conflicts including Syria, Libya, and Yemen exhibit high degrees of fragmentation. In these contexts, the nature and future direction of national institutions is in question. For instance, Libya's bifurcation into two state-like projects since 2014 complicates the mechanisms through which higher education can contribute towards state strengthening. In Yemen, universities under the control of the Houthis since 2015 have experienced replacement of curriculum and some limited research on issues of peace, governance, and the rule of law with ideological indoctrination towards Houthi aims. ${ }^{14}$ Similarly, universities in Iraq and Syria were-although more haphazardly - geared towards the goals of the Islamic State.

\section{Securitisation}

Higher education is increasingly framed as an important front for countering violent extremism (CVE). The popular image of unemployed angry young men posing conflict risk as a trope in youth and security research is now joined by widely cited research finding that a surprisingly high proportion of Jihadi terrorists are university-educated engineers

\footnotetext{
13 Interview. Staff member, UNDP Bangkok Regional Hub. Bangkok, Thailand. October 2019.

14 Focus group. Two Professors at Sana'a University and one Professor, Arman University. Sana'a, Yemen. June 2020.
} 
Table 2 Selected indicators for the nine most fragile contexts in 2019

\begin{tabular}{llll}
\hline Country & $\begin{array}{l}\text { Fragile states index 2019 }_{\text {ranking }^{\mathrm{a}}} \\
\text { Yemen }\end{array}$ & $\begin{array}{l}\text { Gross tertiary enrolment } \\
\text { ratio }^{\mathrm{b}}\end{array}$ & $\begin{array}{l}\text { GDP per } \\
\text { capita }^{\mathrm{c}} \\
\text { (US\$-2019) }^{\text {(U) }}\end{array}$ \\
\hline Somalia & 1 & $10 \%(2011)$ & $998.2(2018)$ \\
South Sudan & 2 & & $126.9(1990)$ \\
Syria & 3 & $40 \%(2016)$ & $1119.7(2015)$ \\
Congo D.R. & 4 & $7 \%(2016)$ & $2032.6(2007)$ \\
Central African Republic & 5 & $3 \%(2012)$ & 545.2 \\
Chad & 6 & $3 \%(2015)$ & 467.9 \\
Sudan & 7 & $17 \%(2015)$ & 709.5 \\
Afghanistan & 8 & $10 \%(2018)$ & 441.5 \\
\hline
\end{tabular}

${ }^{a}$ Fragile States Index 2019. The Fund for Peace. Available online at: https://fundforpeace.org/2019/04/10/ fragile-states-index-2019/

${ }^{\mathrm{b}}$ UNESCO Institute of Statistics. Data accessed 12/08/2020. Available online at: http://data.uis.unesco.org/ index.aspx?queryid=3442\#

${ }^{c}$ World Bank National Accounts Data. Data accessed 12/08/2020. Available online at: https://data.worldbank.org/indicator/NY.GDP.PCAP.CD

(Gambetta and Hertog 2016). It is a harsh truth that higher education can promote violence and insecurity during conflict, for instance, serving as recruiting grounds for militias in post-2003 Iraq and post-2001 Afghanistan (Milton forthcoming). Yet, recent research has however challenged foundational assumptions in much CVE literature that education is the primary vector of radicalisation/de-radicalisation or that Islamic universities axiomatically promote extremism (Thurston 2018).

Growing securitisation of higher education in fragile and conflict-affected contexts-in particular in Islamic societies with extremist non-state armed movements - can have negative effects, affecting how SDG16 itself is interpreted by donors, governments, and university leaders. For instance, fear of association with universities thought to produce violent extremists is increasingly a concern of donors in funding higher education in Southeast Asia including in Indonesia, Malaysia, and southern Thailand. ${ }^{15}$ Incumbent governmentswary of higher education's disruptive force in mass mobilisation-also often advance securitised framings of higher education, for instance, in both Iraq and Syria, university students are often targeted by the state as potential security risks. ${ }^{16}$ By contrast, higher education communities do not routinely envision their contribution towards the headline terms of peace and justice in terms of violence reduction but rather in more transformative ways.

SDG16 has been viewed as an opportunity to further merge security and development agendas. Relevant here is the difference in understanding of 'peace' under SDG16, with many humanitarian and peacebuilding practitioners wary of the introduction of securitised approaches to development (Barakat and Milton 2020). As Julia Paulson rightly identifies, SDG16 targets and indicators align more closely with the concept of negative peace than positive peace. One useful direction here would be to emphasise SDG16+, which offers

\footnotetext{
15 Interview. Staff member, UNDP Bangkok Regional Hub. Bangkok, Thailand. October 2019.

16 Interviews. Syrian and Iraqi university students.
} 
more of a positive peace message than SDG16, incorporating peace-related targets across SDGs including commitment under SDG4 on education to building cultures of peace. Ultimately, further securitisation of higher education in fragile contexts risks the sector's predominant framing in contributing towards SDG16 being cast in negative terms, such as CVE, rather than its potential transformative role.

\section{Politicisation and insecurity}

One of the most direct obstacles to universities in fragile and conflict-affected contexts making SDG16 a central component of their engagement is the threat of violence, insecurity, and subsequent restrictions on academic freedom. Bush and Duggan (2015, p.4) characterise violently-divided societies as 'knowledge-depleted environments' due to stresses including attacks on universities, silencing of public intellectuals, and politicisation of research which together 'inhibit local researchers from contributing to efforts to address the multifaceted forms of violence that the World Development Report 2011 described as the 'main constraint to meeting the Millennium Development Goals'. This critique applies equally to violently-divided societies and the SDGs.

SDG16 engagement is challenging because its scope includes sensitive topics that could increase risks of attacks against universities. As Sabic-El-Rayess and Mansur (2016, p.20) note, 'corruption research carries inherent risks to researchers', and these are amplified in conflict-ridden contexts with impunity for violence. In Libya and Afghanistan, countries where academic freedoms are formally protected under law, violence impedes SDG16 engagement. When asked whether universities engage in peace efforts during the Libyan civil war (2014-2020), former President of Tripoli University explained 'the universities now are totally out of the game because of intimidation, kidnapping, and physical violence'. ${ }^{17}$ Similarly, at Kandahar University—in one of Afghanistan's most conflict-affected provinces - engagement with SDG16-related topics is limited because staff are 'seriously concerned about their safety and see their involvement in such policies as a danger for their future'. ${ }^{18}$ Similarly, in Houthi-controlled areas in Yemen, 'anything that may make students realise issues of governance, corruption, or democracy is not acceptable and will be eliminated with deadly responses, like kidnapping, forced disappearance, and killings'. ${ }^{19}$

Politicisation of engagement with issues related to peace, governance, and justice can also have negative non-violent repercussions for universities. In violently-divided societies research results can become politicised and 'exacerbate tensions, for example, if its implications or conclusions are perceived to be threatening to the interests of one or more groups' (Bush and Duggan 2015, p.5). Engaging with core issues of justice and governance can lead to silencing and sidelining the public role of universities. Luka Kuol (2019) reflects on his time as a Professor in South Sudan, writing that:

When I tried to create academic space within the University of Juba for discussing public policy issues, such as federalism and the presidential decree for the creation

\footnotetext{
17 Online interview. Former President, Tripoli University. May 2020.

18 Interview. Faculty member (rank/faculty anonymous). Kandahar University. May 2020.

19 Focus group. Two Professors at Sana'a University and one Professor, Arman University. Sana'a, Yemen. June 2020.
} 
of more states in South Sudan, I became a political target and was forced to leave the country.

In such contexts, universities may be better served by mobilising resources around and aligning their education, research, and service missions with other SDGs. This would be in line with common institutional responses for universities in conflict zones to become more insular and disengage with their local environment to protect from fallout of conflict (Brewer 2018). Whilst withdrawal from engaging with SDG16 would be unfortunate, at a minimum, donor-funded engagement with universities in fragile contexts should be cognizant of risks. One UN official states that 'universities are areas of vulnerability and risk. It is contextual. Yet, academic knowledge production on these issues should not stop. Higher education has disruptive capacity for state structures'. ${ }^{20}$

Another response is to continue to engage on SDG16-related issues in a de-politicised manner. For instance, in Mozambique - a post-conflict 'success story' at risk of unravelling since 2016-academic freedom is limited by governmental aversion to criticism. Many researchers self-censor and produce de-politicised research, thus limiting peacebuilding contribution as 'academics and civil society can partake only in debates that do not touch on the core issues of power and governance, but rather on 'technical' and service delivery topics such as education or health' (Lühe 2018, p.38). Such de-politicisation reduces higher education to an instrumental function in which critical engagement on peace, governance, or justice is limited. In another example, after the 2011 uprising in Libya, efforts to establish a research centre at Tripoli University were hampered by resistance within university and ministry leadership through association with external UN funding - and several proposed centre names including 'transition', 'change', and 'development' were deemed radical. ${ }^{21}$ One official explained that whilst a research centre with an innocuous name such as 'center for research and cooperation' could have undertaken the identical research mission-on post-conflict recovery and statebuilding - it was the branding that was unacceptable. ${ }^{22}$ This underscores the point that de-politicisation can be as much about framing as about substance. In certain contexts, SDG16 may bring international legitimacy whilst in others it may risk further politicising engagement.

\section{Global-local dynamics-localising SDG16}

Cutting across the higher education-SDGs relationship is tension between the SDGs as a global norm with universal applicability and the broad shift in understanding responses to conflict and fragility from the universal towards local alternatives. Calls to emphasise the local over the global come from various directions (Barakat and Milton 2020). Consequently, a global shift is underway from totalising logics towards relational theories, complex systems, and greater willingness to experiment, accept failure, and search for contextualised solutions in fragile and conflict-affected states (Chandler 2016; Coning 2016). Higher education is affected by these changing local-global dynamics in conflict response. This section begins by considering higher education in localisation of SDG16 in fragile

${ }^{20}$ Interview. Two senior offcials. United Nations Office for Drugs and Crime. April 2020.
${ }^{21}$ Author observation as research assistant on project involving University of Tripoli. 2011-2012.
22 Interview. Senior official. Libyan Economic Development Board. Tripoli, Libya. October 2012. 
contexts, before in the next section considering a more substantive role in supporting contextualised, locally rooted forms of peace and governance.

A major SDG-related challenge is weakness of national-level statistical capacities for collecting and monitoring data, in particular in fragile and conflict-affected societies facing impact of conflict on statistical offices, access barriers for research, and politicisation of information. However, capacities across fragile states are not uniform, with Mali ahead of many non-conflict contexts in SDG16 data collection whilst Zimbabwean universities are collaborating with government-led SGD localisation efforts. ${ }^{23}$ In these areas, higher education can play a role through advanced statistical training. This is important for SDG16 as national statistical offices are often adept at collecting data on health, education, GDP and other long-standing development indices but less experienced in handling statistics on peace, justice or governance (Nygård 2017).

Whilst the SDG framework is a universally applicable framework which lies in tension with localised, endogenous development alternatives, the aspirational nature of SDG16 does afford more space to national actors in localising the goal. In particular, while SDG16 is wide in scope, its open-endedness enabled allows flexibility for states in adopting context-specific policies and means of implementation. There is also variation in global-local dynamics across SDG16. A UNODC official explains 'there are cross-cutting threats agreed upon by states, for instance, anti-crime is almost universally agreed upon'. ${ }^{24}$ Local academic voices and universities - whilst frequently peripheral to global-level SDG technical processes - can articulate context-specific, localised SDG indicators, provide policy research, and facilitate multi-stakeholder dialogue on localising SDGs (UNDP 2019). For instance, Iraqi 'universities of Basra, Anbar, and Karbala are fully engaged with the sustainable development implementation and monitoring process at their local level' in a UNDP pilot project on SDG localisation. ${ }^{25}$

There is, however, a risk of instrumentalising support for higher education in fragile and conflict-affected contexts by making universities part of a globally driven technocratic exercise rather than focusing community service on locally rooted peace and development issues. The SDGs are a highly technocratic measurement process (Mac Ginty 2018). A report from an expert panel on the SDGs and peace states that:

Political Counsellor at the Permanent Mission of Australia to the UN, said that the challenge of the SDGs is not about creation of new goals, but rather about their implementation. "We need managers and accountants now, and not philosophers," he said (IPI 2018).

Framing the SDG role of universities in conflict zones as primarily around target/indicator localisation risks reducing higher education to a technical fix. As Goetschel (2018, p.12) warns, peace research must guard against uncritically accepting or internalising meta-narratives such as the liberal peacebuilding model or SDGs "which constitute particular political or ideological a priori'. The ideal should not be framing higher education as an institutional vector for localising and legitimising SDGs in fragile states but rather empowering universities as a site to explore alternative frameworks for recovery, which could include rejection of universal frameworks including SDG16.

${ }^{23}$ Interview. Senior consultant to UNDP. November 2019.

${ }^{24}$ Interview. Two senior officials. United Nations Office for Drugs and Crime. April 2020.

${ }^{25}$ Online interview. Senior Project Manager, UNDP Iraq. May 2020. 


\section{Global-local dynamics-envisioning alternatives}

This critical role of higher education in exploring alternative pathways for peace and development offers a compelling vision that works counter to predominant modes of liberal peacebuilding. In scholarship on peacebuilding and statebuilding, critiques of liberal peacebuilding centred on theorising pitfalls of universal templates for post-conflict societies. Yet these debates that have re-invigorated peace and conflict studies 'reached something of an impasse' between orthodox defenders of the twin goals of marketisation and democratisation as the pathway to peace and scholars who have critiqued the model as imposing an unsuitable universal blueprint that failed on its own terms and denies local agency and autonomy (Heathershaw 2013; Richmond and Mac Ginty 2014). Local higher education has often been excluded from such externally led interventions. This in part results from pathologising framings of local universities:

As with the mantra that labels local actors as incapable of governing their own political and social affairs, in academia we have seen the trend of perceiving local scholars as incapable of generating knowledge (Musliu and Visoka 2019).

In contrast with this pathologising narrative, throughout the paper it has been seen that higher education in conflict-affected societies can contribute substantively towards peace, governance, and justice. Compared to 'international' academics, 'local' academic voices often possess a comparative advantage in redressing knowledge deficits exhibited in conflict responses. However, their involvement should not be reduced to providing technical fixes to salvage liberal peacebuilding by supplementing with contextual insight. Rather, the sector can comprise an integral aspect of an architecture for exploring alternatives to liberal peacebuilding. Reflecting on a region-wide Peace Studies Master's in the Balkans, Džuverović and Kapidžić (2018, p.124) write that 'universities have the potential and social responsibility to explore and formulate a locally informed bottom-up approach to peacebuilding that may not necessarily reflect either liberal or hybrid peacebuilding'. Similarly, conflict-affected universities play a multi-faceted spatial role whether as neutral grounds, 'zones of civility', or serving 'as a point of nexus between academics, students and administrators and the local, national and international communities' (Burke and Millican 2018, p.231-233).

For proponents of the 'local-local' as an emancipatory alternative to externally engineered social change (Richmond 2013), higher education in conflict-affected societies may not be the obvious choice as a vector through which to localise top-down peacebuilding. Higher education is often framed as an elite good, serving middle class urban constituencies with large public subsidies protected to bolster the legitimacy of fragile regimes during war-to-peace transitions (Stewart et al. 2009). Local academics are often drawn from privileged backgrounds and may even be viewed as 'outsiders' by local communities in conflict-affected areas of their home country. Yet, finer typological understanding of conflict actors can avoid romanticising 'the local'. It is important for theories of the local in peacebuilding to 'distinguish between community-based women groups, religious associations, or traditional authorities on the one hand, and formalised, capital-based civil-society organisations on the other' (Van Leeuwen et al. 2019, p.4).

Higher education in this schema would be categorised alongside capital-based civil society as but one local actor that has neither a claim as sole representative of the local nor justification for dismissal as insufficiently authentic. Support for this can be found in an ethnographic study of Somaliland finding that contrary to critiques that the 'modern' 
style of education offered by the University of Hargeisa's Institute of Peace and Conflict Studies is extraverted or mimetic, modernity is embraced by students and staff in ways that do not devalue modern or indigenous sources of knowledge (Woolner 2016). Universities themselves are sites of contested hybridity and are undergoing often simultaneous multiscalar processes of localisation, regionalisation, and internationalisation (Välimaa 2004). For instance, a study of higher education in Myanmar's post-authoritarian transition finds that reform processes are influenced by twin discourses of neoliberalisation and marketisation set against a culturally grounded, inclusive developmental agenda in service of local needs (Kandiko Howson and Lall 2019).

\section{Conclusion}

The paper began by introducing the SDGs in relation to higher education. It then proceeded to identify ways in which higher education in fragile and conflict-affected contexts can contribute towards SDG16 through education, research, external engagement, and governance and operations. Some key highlights are that teaching on SDG16 holds the most promise when integrated across curriculum in a trans-disciplinary manner and that research agendas in fragile contexts are highly donor-driven and could build more effective capacity through genuine partnership with universities. Furthermore, it was seen that universities are engaging SDG16-related policy issues although there are many barriers whilst university governance can positively or negatively influence participation and institutions. The paper then highlighted four cross-cutting dynamics affecting university agency in engaging with SDG16 in fragile and conflict-affected contexts.

Several major conclusions emerge from the paper. Firstly, universities in fragile and conflict-affected contexts face many severe challenges which lead to widespread perceptions that any higher education is impossible in such circumstances, let alone specialist contributions to SDG16. The paper has shown multiple examples of higher education communities - in some but not all of the most fragile contexts-engaging substantively with SDG16-related issues. This challenges pathologising narratives, yet we should also guard against raising expectations. Secondly, SDGs have major potential for resource mobilisation and SDG16 could help universities in resource-challenged fragile states mobilise resources, build capacities, and gain greater ownership over knowledge on SDG16-related issues. Yet, it has been seen that, in some contexts, university engagement is highly politicised and can even bring risk of violent attack. Whilst not discouraging such engagement, at a minimum there should be awareness of the potential sensitivities involved.

Thirdly, a recurrent theme was what may be framed as the constitutive versus instrumental role of higher education. One response to the above-mentioned politicisation is de-politicisation of engagement. Yet, this is not just product of response to local threats to academic freedom but also the technical nature of SDG process and was seen in the donor-driven research culture reducing local researchers to sub-contracted assistance with little space for critical analysis. Fourthly, unequal North/South power differentials have been seen in research partnerships and global-local dynamics. Whilst SDG16 will likely increase research funding opportunities in fragile contexts, it is unclear whether this will support more equitable power relations with Northern knowledge producers.

Finally, SDG16 represents a step forward in inclusion of peace, governance, and justice on development agendas, yet there are barriers and trade-offs involved. Ultimately, the contribution of higher education to peace, governance, and justice goes far beyond SDG16, 
which itself results from an untidy political compromise with wide conceptual scope and unrealistic indicators. Furthermore, there is tension between peace and governance axes of SDG16, with 'peace' interpreted by some in negative, securitised framings. Rather than aligning with specific SDG16 targets and indicators, focus should be on better enabling universities in fragile and conflict-affected contexts to substantively contribute to the greater question of how to envision and achieve alternative pathways to more peaceful, just, and inclusive societies.

Funding Open Access funding provided by the Qatar National Library.

\section{Compliance with ethical standard}

Conflict of interest The authors declare that they have no conflict of interest.

Open Access This article is licensed under a Creative Commons Attribution 4.0 International License, which permits use, sharing, adaptation, distribution and reproduction in any medium or format, as long as you give appropriate credit to the original author(s) and the source, provide a link to the Creative Commons licence, and indicate if changes were made. The images or other third party material in this article are included in the article's Creative Commons licence, unless indicated otherwise in a credit line to the material. If material is not included in the article's Creative Commons licence and your intended use is not permitted by statutory regulation or exceeds the permitted use, you will need to obtain permission directly from the copyright holder. To view a copy of this licence, visit http://creativecommons.org/licenses/by/4.0/.

\section{References}

Babo, A. (2019). Postwar recovery and student academic freedom in Côte d'Ivoire. AAUP Journal of Academic Freedom, 10, 1-17.

Bhargava, V., Elmendorf, E., Gray, S., Kafka, B., Ritchie, D., and Little, S. (2019). Expanding civil society contributions to the governance agendas of the sustainable development goals and international financial institutions. Partnership for Transparency.

Barbara, J., \& Walsh, L. (2018). Realising the potential of universities as significant development actors in post-conflict societies: a case study of the Solomon Islands National University. Forum for Development Studies, 45(1), 47-69.

Barakat, S., \& Milton, S. (2020). Localisation across the Humanitarian-Development-Peace Nexus. Journal of Peacebuilding and Development, 15(2), 147-163.

Brewer, J. (2018). Queen's University Belfast in Times of in Violence and Peace Chapter 4. In J. Millican (Ed.), Universities and Conflict: The Role of Higher Education in Peacebuilding and Resistance. London: Routledge.

Burke, F., \& Millican, J. (2018). Working with institutions, academics and students to confront questions of peacebuilding and resistance Chapter 4. In J. Millican (Ed.), Universities and Conflict: The Role of Higher Education in Peacebuilding and Resistance. London: Routledge.

Bush, K., \& Duggan, C. (Eds.). (2015). Evaluation in the extreme: Research, impact and politics in violently divided societies. SAGE: New Delhi.

Chandler, D. (2016). How the world learned to stop worrying and love failure: big data, resilience and emergent causality. Millennium: Journal of International Studies, 44(3), 391-410.

Collier, P., Elliott, V. L., Hegre, H., Hoeffler, A., Reynal-Querol, M., Sambanis, N. (2003). Breaking the Conflict Trap : Civil War and Development Policy. A World Bank policy research report. Washington, DC: World Bank and Oxford University Press.

Coning, C. (2016). Implications of complexity for peacebuilding policies and practices. In E. Brusset, C. Coning, \& B. Hughes (Eds.), Complexity thinking for peacebuilding practice and evaluation (pp. 19-48). New York: Palgrave Macmillan.

Court, D. (1980). The development ideal in higher education: the experience of Kenya and Tanzania. Higher Education, 9(6), 657-680. 
Donoghue, D., and Khan, A. (2019). Achieving the SDGs and 'leaving no one behind': maximising synergies and mitigating trade-offs. Overseas Development Institute.

Douglass, J. A. (2016). The New Flagship University: Changing the paradigm from global ranking to national relevancy. Basingstoke: Palgrave Macmillan.

Dupuy, K., Gates, S., Nygård, H., Rudolfsen, I., Strand, H., \& Urdal, H. (2016). Trends in armed conflict, 1946-2015. Peace Research Institute Oslo: Conflict Trends.

Džuverović, N., and Kapidžić, D. (2018). Bridging the 'International-Local Gap' in peacebuilding through academic cooperation: The Balkan Master's Program in Peace Studies. Chapter 8 in Millican, J. (ed). Universities and Conflict: The Role of Higher Education in Peacebuilding and Resistance. Routledge.

El-Jardali, F., Ataya, N., and Fadlallah, R. (2018). Changing roles of universities in the era of SDGs: rising up to the global challenge through institutionalising partnerships with governments and communities. Health Research Policy and Systems, 16, Article 38.

Fast, L. (2019). Researching local humanitarian action through partnerships with local actors. London: Overseas Development Institute.

Feuer, H., Hornidge, A.K., and Schetter, C. (2013). Rebuilding knowledge: Opportunities and risks for higher education in post-conflict regions. ZEF Working Paper Series. Working Paper 121. Bonn: Center for Development Research: University of Bonn.

Fishstein, P., Paterson, A., and Roe, A. (2012). Mapping of research capacity in Afghanistan. Department for International Development of the Government of the United Kingdom.

Gambetta, D., and Hertog, S. (2016). Engineers of jihad: The curious connection between violent extremism and education. Princeton University Press.

Goetschel, L. (2018). The interaction of peace research and local context. Paper 2 in Jones, B. (ed). Knowledge for peace: Transitional justice, knowledge production and an agenda for research. Swiss Peace.

GoS. (2018). Voluntary national review 2018: Implementation of agenda 2030 and the SDGs for peace and development in the Sudan. Government of Sudan.

Heathershaw, J. (2013). Towards better theories of peacebuilding: beyond the liberal peace debate. Peacebuilding, 1(2), 275-282.

Hoinathy, R., \& Eizenger, D. (2019). The State of Secularism in Chadian Higher Education Testing Perceived Ties to Violent Extremism. RESOLVE Network.

Ibrahimi, N. (2014). Bureaucratic policies and patronage politics: Prospects and challenges of private higher education in Afghanistan. Briefing Paper. Afghan Analysts Network.

INASP. (2018). Capacity development in 'harder to reach' places: Bringing together people, activities and learning to explore work in Sierra Leone and the Somali regions. INASP.

IPI. (2018). Bringing words to life: How are the SDGs supporting peace, justice, and inclusion? International Peace Institute. 12 July.

Janoušková, S., Hák, T., \& Moldan, B. (2018). Global SDGs assessments: Helping or confusing indicators? Sustainability, 10(5), 1540.

Jok, J. M. (2016). Research and Knowledge Systems in South Sudan. Oxford: INASP.

Kamua, M., Chasek, P., \& O'Connor, D. (2018). Transforming multilateral diplomacy: The inside story of the Sustainable Development Goals. Abingdon: Routledge.

Kandiko Howson, C., and Lall, M. (2019). Higher education reform in Myanmar: neoliberalism versus an inclusive developmental agenda. Globalisation, Societies and Education

Kuol, L. (2019). The future of disasters studies: New disasters and the case of the Horn of Africa. Disasters, $43(\mathrm{~S} 1), \mathrm{S} 28-\mathrm{S} 35$.

Lockhart, C., and Vincent, S. (2013). Ending extreme poverty in fragile and conflict-affected situations. Background Research Paper. High Level Panel on the Post-2015 Development Agenda.

Lühe, U. (2018). The politics and practice of political research in Mozambique. Paper 6 in Jones, B. (ed). Knowledge for peace: transitional justice, knowledge production and an agenda for Research. Swiss Peace.

Mac Ginty, R. (2018). The limits of technocracy and local encounters: The European Union and peacebuilding. Contemporary Security Policy. 39(1), 166-179

Malejacq, R., \& Mukhopadhyay, D. (2016). The 'Tribal Politics' of Field Research: A Reflection on Power and Partiality in 21st-Century Warzones. Perspectives on Politics. 14(4), 1011-1028.

Mcloughlin, C. (2012). Topic guide on fragile states. Governance and Social Development Resource Centre: University of Birmingham.

McCowan, T. (2019). Higher education for and beyond the Sustainable Development Goals. Cham: Palgrave Macmillan.

Millican, J. (2018). Universities and conflict: The role of higher education in peacebuilding and resistance. London: Routledge.

Milton, S. (2018). Higher education and post-conflict recovery. Palgrave Macmillan. 
Milton, S. (2020). Universities in post-2003 Iraq: Coalition and Iraqi responses to violence and insecurity. Research in Social Movements, Conflicts and Change.

Musliu, V., \& Visoka, G. (2019). Introduction: Local critiques of intervention and statebuilding Chapter One. In G. Visoka \& V. Musliu (Eds.), Unravelling liberal interventionism: Local critiques of statebuilding in Kosovo. Abingdon: Routledge.

Nygård, H. (2017). Achieving the sustainable development agenda: The governance - conflict nexus. International Area Studies Review, 20(1), 3-18.

Oketch, M., McCowan, T., and Schendel, R. (2014). The impact of tertiary education on development. Institute of Education/UK Aid.

Pherali, T., and Abu Moghli, M. (2019). Higher education in the context of mass displacement: Towards sustainable solutions for refugees. Journal of Refugee Studies.

Pherali, T., \& Lewis, A. (2019). Developing global partnerships in higher education for peacebuilding: A strategy for pathways to impact. Higher Education, 78(4), 729-744.

Richmond, O. (2013). Peace formation and local infrastructures for peace. Alternatives: Global, Local, Political, 38(4), 271-287.

Richmond, O., \& Mac Ginty, R. (2014). Where now for the critique of the liberal peace? Cooperation and Conflict, 50(2), 171-189.

Samman, E., Lucci, P., Hagen-Zanker, J., Bhatkal, T., Simunovic, A.T., Nicolai, S., Stuart, E., and Caro, C. (2018). SDG progress: Fragility, crisis and leaving no one behind. Overseas Development Institute/ International Rescue Committee.

SDSN. (2017). Getting started with the SDGs in universities: A guide for universities, higher education institutions, and the academic sector. Sustainable Development Solutions Network.

Shefaie, M.Z. (2019). Conference presentation at 'Conference on Role of Universities in Implementing the SDGs in Afghanistan', Kateb University, August 2019.

Strand, H., Aas Rustad, S., Urdal, H., and Nygård, H. (2019). Trends in armed conflict, 1946-2018. Conflict Trends. Peace Research Institute Oslo

Stewart, F., Brown, G., and Cobham, A. (2009). The implications of horizontal and vertical inequalities for tax and expenditure policies. CRISE Working Paper Number 65. Oxford: Centre for Research on Inequality, Human Security and Ethnicity.

Sabic-El-Rayess, A., \& Mansur, N. (2016). Favor reciprocation theory in education: New corruption typology. International Journal of Educational Development, 50, 20-32.

Thurston, A. (2018). Campuses and conflict in the Lake Chad Basin: Violent extremism and the politics of religion in higher education. RESOLVE Network.

UNDP. (2019). SDG localization in ASEAN: Experiences in shaping policy and implementation pathways. United Nations Development Programme.

Van Leeuwen, M., Nindorera, J., Kambale Nzweve, J.L., and Corbijn, C. (2019). The 'local turn' and notions of conflict and peacebuilding: Reflections on local peace committees in Burundi and eastern DR Congo. Peacebuilding.

Välimaa, J. (2004). Nationalisation, localisation and globalisation in Finnish higher education. Higher Education, 48(1), 27-54.

Varisco, A. E. (2018). Research in security sector reform policy: The case of Sierra Leone. London: Palgrave Macmillan.

Woolner, C. (2016). Education and extraversion: naming, valuing and contesting 'modern' and 'indigenous' knowledge in post-war Somaliland. Journal of Eastern African Studies, 10(3), 413-433.

World Bank. (2011). World human development report 2011: Conflict, security and development. World Bank Group.

World Bank. (2018). Maximizing the impact of the World Bank Group in fragile and conflict-affected situations. World Bank Group.

Publisher's Note Springer Nature remains neutral with regard to jurisdictional claims in published maps and institutional affiliations. 